Abstracta Iranica Abstracta Iranica

Revue bibliographique pour le domaine irano-aryen

Volume 30 | 2010

Comptes rendus des publications de 2007

\title{
«The Bazaar of Tehran during the Nineteenth Century ». The Journal of Sophia Asian Studies, 25, 2007, pp. 161-195. [in Japanese]
}

Akihiko Yamaguchi

\section{(2) OpenEdition}

Journals

Édition électronique

URL : http://journals.openedition.org/abstractairanica/37790

DOI : 10.4000/abstractairanica.37790

ISSN : 1961-960X

Éditeur :

CNRS (UMR 7528 Mondes iraniens et indiens), Éditions de l'IFRI

Édition imprimée

Date de publication : 8 avril 2010

ISSN : 0240-8910

Référence électronique

Akihiko Yamaguchi, « "The Bazaar of Tehran during the Nineteenth Century ». The Journal of Sophia Asian Studies, 25, 2007, pp. 161-195. [in Japanese] », Abstracta Iranica [En ligne], Volume 30 | 2010, document 143, mis en ligne le 08 avril 2010, consulté le 26 septembre 2020. URL : http:// journals.openedition.org/abstractairanica/37790; DOI : https://doi.org/10.4000/abstractairanica. 37790

Ce document a été généré automatiquement le 26 septembre 2020.

Tous droits réservés 


\title{
« The Bazaar of Tehran during the Nineteenth Century ». The Journal of Sophia Asian Studies, 25, 2007, pp. 161-195. [in Japanese]
}

\author{
Akihiko Yamaguchi
}

1 This well-written article analyses the development process of the Bazaar of Teheran during the 19th century as well as its compositions and ownership relations. The particular interest consists in the role of waqf in the development and maintenance of the Bazaar. The author challenges the accepted notion, according to which the waqf institution generally contributed to the expansion of commercial facilities and that most of estates in marketplaces were waqf property. According to the author, in 19thcentury Tehran, Qajar rulers played a significant part in the development of the market center by building bazaars and shops as well as purchasing sarays. Few of these estates, however, were endowed as waqf. In fact, only a few of shops in the Bazaar were waqf property. As for the sarays, which were used as shop, office, house, atelier, more than half of them were, at least partly, transformed into waqf. More interestingly, these sarays were increasingly shared by several owners, who established small waqfs in their portions. These findings indicates that, as far as the Bazaar of Tehran during the 19th century is concerned, the waqf institution did not much contribute to the expansion of the commercial complex itself, but it principally helped to maintain commercial facilities built in the Bazaar. 
INDEX

Thèmes : 4.2.1. Safavides et Qâjârs

\section{AUTEURS}

AKIHIKO YAMAGUCHI

University of Sacred Heart - Tokyo 